\title{
28 Research Square \\ Piezoelectric Properties of Lead Zirconate Titanate Ceramics at Low and High Temperatures
}

\section{Mitsuhiro Okayasu ( $\nabla$ mitsuhiro.okayasu@utoronto.ca )}

Okayama University

\section{Masakazu Okawa}

Okayama University: Okayama Daigaku

\section{Research Article}

Keywords: lead zirconate titanate ceramic, piezoelectric properties, electric generation voltage, domain switching

Posted Date: October 28th, 2020

DOl: https://doi.org/10.21203/rs.3.rs-97421/v1

License: (1) This work is licensed under a Creative Commons Attribution 4.0 International License. Read Full License

Version of Record: A version of this preprint was published at Advances in Applied Ceramics on March 28th, 2021. See the published version at https://doi.org/10.1080/17436753.2021.1904765. 


\section{Abstract}

The material properties and damage characteristics of lead zirconate titanate (PZT) ceramics were investigated at various temperatures $\left(-190^{\circ} \mathrm{C}\right.$ to $\left.180^{\circ} \mathrm{C}\right)$. A positive voltage was obtained when the sample was cooled from $20^{\circ} \mathrm{C}$ to $-190^{\circ} \mathrm{C}$, while a negative voltage was obtained when the sample was warmed from $-190^{\circ} \mathrm{C}$ to $180^{\circ} \mathrm{C}$. The difference between the positive and negative values depended on the thermal stress. Compressive stress generated a more positive voltage in the cooling process, while tensile stress led to a more negative voltage in the warming process). The voltage values also depended on the cooling (or warming) rate of the sample, e.g., the greater the cooling (or warming) rate, the greater the voltage. When cyclic loading was conducted mechanically at $-190^{\circ} \mathrm{C}$, the voltage reduced, but it was recovered after warming to $20^{\circ} \mathrm{C}$. Damage of the PZT ceramic ( $90^{\circ}$ domain switching) was detected when the sample was cooled to $-190^{\circ} \mathrm{C}$. This was due to the high thermal stress, resulting in a low voltage.

\section{Introduction}

Lead zirconate titanate ( $\left.\mathrm{PZT}: \mathrm{Pb}(\mathrm{Zr}, \mathrm{Ti}) \mathrm{O}_{3}\right)$ ceramics have seen widespread use in a large number of engineering applications, such as in various actuators for precision positioning, vibration suppression equipment, power transducers and vibration sensors. In these applications, PZT ceramics are sometimes used under severe conditions, e.g. at high (or low) temperatures and high humidity. Because the perovskite structure is highly crystalline, ferroelectric lead titanate films have recently been used at high temperatures [1]. Using X-ray diffraction analysis, the crystallization temperatures of piezoelectric ceramics of different chemical compositions, lead titanate (PT), lead zirconate (PZ) and PZT, have been shown to increase in the sequence PT $<\mathrm{PZ}<\mathrm{PZT}$ at temperatures in the range of $380{ }^{\circ} \mathrm{C}$ to $500{ }^{\circ} \mathrm{C}[2]$. The piezoelectric properties of PZT worsen, resulting in a low value of $k_{33}$, as heating to the Curie temperature $\left(300{ }^{\circ} \mathrm{C}\right)$ occurs, due to a change of the lattice system from tetragonal to cubic [3]. The fabrication of capacitive ultrasonic transducers using surface micromachining techniques and a low-temperature process has been investigated [4]. The piezoelectric properties of PZT ceramics decrease when the sample is cooled. Zhang et al. [5] examined the dielectric and piezoelectric properties of PZT ceramics at temperatures from $-268.8^{\circ} \mathrm{C}$ to $27^{\circ} \mathrm{C}$. They found that the material properties converge as the temperature is decreased down to the temperature of liquid helium. Yakushev and Shalimov [6] reported that an improvement of the piezoelectric properties of PZT ceramics occurs with low temperature cyclic treatment. Some researchers have examined the temperature-dependent behavior of the piezoelectric properties in constitutive relations using a thermodynamic approach [7]. They found that the electrostriction coefficient is affected by the chemical composition. The temperature dependence of the piezoelectric properties of PZT ceramics plays a significant role in their design for engineering applications, although there is little information on this available. In particular, information about the change of the piezoelectric properties of PZT ceramics at low and high temperatures could be significant for the design process. Therefore, the material properties of PZT ceramics were investigated over a wide temperature range under the static and cyclic loading. 


\section{Materials And Experimental Procedures}

Figure 1 shows a schematic illustration of the piezoelectric ceramic and the experimental setup used in this work. The piezoelectric ceramics used were a commercial circular membrane $\mathrm{PbZrTiO}_{3}$ base ceramic $(\varphi 8.0 \mathrm{~mm} \times 0.17 \mathrm{~mm})$ and a bulk PZT ceramic $(5 \mathrm{~mm} \times 3 \mathrm{~mm} \times 3 \mathrm{~mm})$. The circular membrane ceramic was attached to a thin brass plate $(\varphi 12.2 \mathrm{~mm} \times 0.15 \mathrm{~mm})$, and silver-based electrode plating was coated on its surface. The ceramic had a convex shape with a deflection value of $0.2 \mathrm{~mm}$, see Fig. 1(a). The material properties of the ceramic, brass and silver are as follows. Elastic constant (E): $82 \mathrm{GPa}$ [8], 103 $\mathrm{GPa}$ and $82.7 \mathrm{GPa}$. Thermal expansion coefficient $(a): 17.5 \times 10^{-6} /{ }^{\circ} \mathrm{C}, 7.5 \times 10^{-6} /{ }^{\circ} \mathrm{C}$, and $19.7 \times 10^{-6} /{ }^{\circ} \mathrm{C}$. The ceramic consisted of a tetragonal structure with aspect ratio $c / a=1.014$. The nominal grain size of the ceramic was about $5 \mu \mathrm{m}$ in diameter.

To examine the electricity generation characteristics of the PZT ceramics, static and cyclic mechanical loading were used. Mechanical loading was applied at the center of the sample, see Fig. 1(b). Static loading was applied to the sample at $1 \mathrm{~mm} / \mathrm{min}$, and cyclic loading was applied with an $R$ ratio of 0.05 with a frequency of $0.25 \mathrm{~Hz}$. The maximum cyclic loading $\left(P_{\text {max }}\right)$, was determined by the bending yield strength $\left(P_{\mathrm{y}}\right)$ of the ceramic, so that $P_{\mathrm{max}}<0.8 P_{\mathrm{y}}$. The voltage generated from the ceramics was measured using a digital multimeter (8846A, Fluke).

The piezoelectric properties were further investigated at various temperatures $\left(-190^{\circ} \mathrm{C}\right.$ to $\left.180^{\circ} \mathrm{C}\right)$. The ceramic was cooled to the low temperatures using liquid nitrogen $\left(20^{\circ} \mathrm{C}\right.$ to $\left.-190{ }^{\circ} \mathrm{C}\right)$, and heated to the high temperatures using a heater $\left(20^{\circ} \mathrm{C}\right.$ to $\left.180^{\circ} \mathrm{C}\right)$, as shown in Fig. 1 (c). A ceramic heater heated to about $800{ }^{\circ} \mathrm{C}$ was used. To re-heat the sample from $-190^{\circ} \mathrm{C}$ to $20^{\circ} \mathrm{C}$, the sample was put into cold water. The different heating methods were used in order to change the heating rate.

The microstructural and damage characteristics of the PZT ceramics were examined using electron backscatter diffraction (EBSD). The sample surfaces were polished to a mirror finish using colloidal silica. The EBSD analysis was executed using a JEOL-JSM-7001F SEM with an acceleration voltage of $15 \mathrm{kV}$, a beam current of $10 \mathrm{nA}$ and a step size of $0.1 \mu \mathrm{m}$.

\section{Results And Discussion 3.1. Static loading}

Figure 2 shows how the voltage ( $V$ ) varied during static bending loading at $-190^{\circ} \mathrm{C}$ and $20^{\circ} \mathrm{C}$. The ceramics were loaded until a sample deflection of about $1.8 \mathrm{~mm}$ was achieved. As seen in the early loading stage at $20^{\circ} \mathrm{C}$, the electric voltage increased to about $3.5 \mathrm{~V}$, at which time the ceramic was deflected by $0.2 \mathrm{~mm}$. With further loading, the voltage decreased to 0 and then with further loading still, generated a negative voltage. Similar variation of the voltage was seen at $-190^{\circ} \mathrm{C}$; however, the maximum voltage (about $2.7 \mathrm{~V}$ ) was lower than that at room temperature, and a negative voltage was not obtained. The different positive and negative voltages were generated due to different amounts of stress. 
Differences in the voltages at $-190^{\circ} \mathrm{C}$ and $20^{\circ} \mathrm{C}$ were related to the material properties, which will be discussed in a later section of this paper.

Figure 3 shows the profile of the ceramic before and after bending loading. The convex shape of the ceramic is formed at $20^{\circ} \mathrm{C}$ before the loading. The deflection of the convex shape is about $0.2 \mathrm{~mm}$, as shown in Fig. 1, but the profile is altered after the loading, which causes the ceramic to be deformed permanently to a concave shape, shown by the yellow lines. Compressive stress occurs early in the loading process due to the convex shape of the ceramic, while tensile stress is generated later in the process, because of the permanent deforamtion. This causes the voltage to change from positive to negative (Fig. 2).

Figure 3 also shows the profile of the ceramic plate at $-190^{\circ} \mathrm{C}$ before mechanical loading (see the blue dotted line). It can be seen that the ceramic is significantly bent with a convex shape, due to the high stress caused by the different thermal expansion coefficients of the brass plate and PZT ceramic. As severely bent PZT ceramic results in high compressive stress during the loading process, negative voltages were not obtained for the ceramic at $-190^{\circ} \mathrm{C}$, as shown in Fig. 2 .

Figure 4 shows how the maximum voltage varies as a function of the sample temperature. Figure 4(a) shows that the voltage increases to about $40 \mathrm{~V}$ immediately after the sample is put in liquid nitrogen and is cooled from $20^{\circ} \mathrm{C}$ to $0{ }^{\circ} \mathrm{C}$. Upon further cooling to about $-100^{\circ} \mathrm{C}$, the voltage is relatively stable. This may be an effect of heat insulation, due to the air gap created around the sample surface. The voltage increases to $100 \mathrm{~V}$ when the sample temperature is decreased from $-120^{\circ} \mathrm{C}$ to $-190{ }^{\circ} \mathrm{C}$, and the cooling rate increases to about $-70^{\circ} \mathrm{C} / \mathrm{s}$. However, the voltage decreases to 0 when the sample temperature becomes stable at $-190^{\circ} \mathrm{C}$ for a certain period of time, i.e. a spontaneous electric polarization cannot be reversed in the presence of an electric field.

When the ceramic, cooled to $-190^{\circ} \mathrm{C}$, is put into water Fig. $4(\mathrm{~b})$, a negative voltage $(-80 \mathrm{~V})$ is generated rapidly in the temperature range of $-190^{\circ} \mathrm{C}$ to $-150{ }^{\circ} \mathrm{C}$. This is followed by a decrease of the voltage during warming to $20^{\circ} \mathrm{C}$, while the rate of increase of the sample temperature decreases. This could be due to the weak electric field of the PZT ceramic, i.e., the lower the heating rate, the lower the electric generation. Note that the reason for the negative electric voltage is considered to be the thermal tensile stress applied to the PZT ceramic.

The ceramic was further warmed from $20^{\circ} \mathrm{C}$ to $180^{\circ} \mathrm{C}$ using the heater, and the voltage increased slowly without saturation, Fig. 4 (c). This is unlike the result of the heating process in water $\left(-190^{\circ} \mathrm{C}\right.$ to $\left.20^{\circ} \mathrm{C}\right)$. This reason is the low heating rate of about $12{ }^{\circ} \mathrm{C} / \mathrm{s}$ when using the heater $\left(20^{\circ} \mathrm{C}\right.$ to $\left.180^{\circ} \mathrm{C}\right)$, compared to $60{ }^{\circ} \mathrm{C} / \mathrm{s}$ when using the cold water $\left(-190^{\circ} \mathrm{C}\right.$ to $\left.20^{\circ} \mathrm{C}\right)$. It is of interest to note that the rate of increase of the voltage changes at around $70^{\circ} \mathrm{C}$, as indicated by the dashed circle. This may be due to a change in the lattice or material characteristics [9]. However, there is no clear evidence of this, so further discussion will be required in the future.

\subsection{Cyclic loading}


The voltage was further investigated under cyclic loading at low temperature $\left(-190^{\circ} \mathrm{C}\right)$ and room temperature (before and after cooling to $-190^{\circ} \mathrm{C}$ ). Figure 5 shows the voltage obtained during the cyclic loading. Note that the cyclic loading at $-190^{\circ} \mathrm{C}$ was performed in liquid nitrogen. Figure 5 shows that a lower voltage was detected at the lower temperature $\left(V_{\max }=15 \mathrm{~V}\right)$. This is about $70 \%$ lower than the voltage obtained at $20^{\circ} \mathrm{C}\left(V_{\max }=45 \mathrm{~V}\right)$. The low voltage at $-190{ }^{\circ} \mathrm{C}$ is due to the thermal stress at low temperatures, as shown in Fig. 3. In previous work, piezoelectric properties were measured in a temperature range between $-288.8^{\circ} \mathrm{C}$ and the Curie point on undoped and Fe-doped PZT samples, and a pronounced relaxation below $127^{\circ} \mathrm{C}$ occurred due to domain wall vibrations [10]. Zhang et al. have also examined dielectric and piezoelectric properties of modified lead titanate zirconate ceramics at temperatures between $-288.8^{\circ} \mathrm{C}$ and $27^{\circ} \mathrm{C}$, and piezoelectric properties, including the piezoelectric constant, worsened with decreasing sample temperature $[5,11]$.

The voltage of the ceramic increases at $20^{\circ} \mathrm{C}$ after warming from $-190^{\circ} \mathrm{C}$ (Fig. $5(\mathrm{~b})$ ); however, the maximum voltage is slightly lower than that obtained before cooling to $-190{ }^{\circ} \mathrm{C}$ (see the red line vs. the blue dashed line). This may be attributed to damage of the ceramic ( $90^{\circ}$ domain switching), arising from the high thermal stress. To verify this, the thermal stress of the ceramic was calculated. The different strain values $(\varepsilon)$ caused by the different thermal shrinkages of the brass and the PZT ceramic result in high stress on the PZT ceramic. The thermal strain can be estimated using the formula $\varepsilon=a \times \Delta T$. It is clarified using this formula that $\varepsilon_{\mathrm{PZT}}=0.0016$ and $\varepsilon_{\text {brass }}=0.0037$. Knowing the different strain values, the thermal stress of the PZT ceramic can be calculated using the formula $\sigma=E_{\mathrm{PZT}} \times\left\{\left(\varepsilon_{\mathrm{PZT}}-\varepsilon_{\mathrm{brass}}\right) / 2\right\}=82$ $\mathrm{GPa} \times 10^{9} \times(-0.00105)=-86.1 \mathrm{MPa}$ (in compressive stress).

To examine whether or not $90^{\circ}$ domain switching occurs in the PZT ceramic, an attempt was made to analyze the crystal orientation characteristics using the bulk PZT ceramic after compressive stress (86.1 MPa) was mechanically applied. The crystal orientations obtained before and after application of compressive stress are shown in Fig. 6 . The observations were made in the same area of the sample before and after loading. Figure 6 shows that the crystal orientations were changed after the application of compressive stress, and $90^{\circ}$ domain switching occurred (see the pole figures with the lattice formations). From this result it can be inferred that the decrease of the electric voltage after the cooling process is influenced by material failure, i.e., domain switching. One of the authors has examined the domain switching characteristics using a similar PZT ceramic [12]. In that study, domain switching was detected when the bending loading was more than $0.8 P_{\mathrm{y}}$ (bending yield strength).

\section{Conclusions}

In this work, the material properties and damage characteristics of PZT ceramics were investigated under static and cyclic loading at low and high temperatures $\left(-190^{\circ} \mathrm{C}\right.$ to $\left.180^{\circ} \mathrm{C}\right)$. The results can be summarized as follows:

(1) A positive voltage was generated when the sample was cooled from $20^{\circ} \mathrm{C}$ to $-190^{\circ} \mathrm{C}$, whereas a negative voltage was generated when the sample was heated from $-190^{\circ} \mathrm{C}$ to $180^{\circ} \mathrm{C}$. The change in the 
voltage was attributed to different thermal stress, i.e. compressive stress of the ceramic generated the positive voltage, whereas tensile stress led to the negative voltage. The voltage was also affected by the cooling (or warming) rate of the sample, i.e. the greater the cooling (or warming) rate, the greater the voltage.

(2) Upon cyclic loading, the voltage of the ceramic decreased when the sample was cooled to $-190^{\circ} \mathrm{C}$, although the voltage was recovered after warming the sample to room temperature $\left(20^{\circ} \mathrm{C}\right)$. However, damage of the ceramic occurred when the sample was cooled to $-190^{\circ} \mathrm{C}$, due to high thermal stress $\left(90^{\circ}\right.$ domain switching), which resulted in a reduction of the voltage.

\section{References}

1. Duffy Jr W, Cheng BL, Gabbay M, Fantozzi G. Anelastic behavior of barium-titanate-based ceramic materials. Metall Mater Trans A 1995, 26: 1735-1739.

2. Wilkinson AP, Speck JS, Cheetham AK. In situ C-ray diffraction study of crystallization kinetics in $\mathrm{PbZr}_{1-\mathrm{x}} \mathrm{Ti}_{\mathrm{x}} \mathrm{O}_{3}(\mathrm{PZT}, \mathrm{x}=0.0,0.55,1.0)$. Chem Mater 1994, 6: 750-754.

3. Okayasu M, Otake M, Bitoh T, Mizuno M. Temperature dependence of the fatigue and mechanical properties of lead zirconate titanate piezoelectric ceramics. Int J Fatigue 2009, 31: 1254-1261.

4. Cianci E, Foglietti V, Memmi D, Caliano G, Caronti A, Pappalardo M. Fabrication of capacitive ultrasonic transducers by a low temperature and fully surface-micromachined process. J Int Soc Precision Eng Nanotech 2002, 26: 347-354.

5. Zhang XL, Chen ZX, Cross, W.A. Schulze, Dielectric and piezoelectric properties of modified lead titanate zirconate ceramics from 4.2 to 300K. J Mater Sci 1983, 18: 968-972.

6. Yakushev PN, Shalimov VV. Improving the piezoelectric properties of PZT ceramics by lowtemperature cycling. Tech Phys Lett 2020, 46: 182-185.

7. Moon W, Busch-Vishniac IJ. Modeling of piezoelectric ceramic vibrators including thermal effects. Part I. Thermodynamic property considerations. J Acoust Soc Am 1995, 93: 403-412.

8. Bourim E, Idrissi H, Cheng B, Gabbay M, Fantozzi G. Elastic modulus and mechanical loss associated with phase transitions and domain walls motions in PZT based ceramics. J de Phys IU 1996, 6: C8633-636.

9. Bouzid A, Bourim EM, Gabbay M, Fantozzi G. PZT phase diagram determination by measurement of elastic moduli. J Eur Ceram Soc 2005, 25: 3213-3221.

10. Herbiet R, Robels U, Dederichs H, Arlt G. Domain wall and volume contributions to material properties of PZT ceramics. Ferroelectrics 1989, 98: 107-121.

11. Fuji Ceramics Co., Technical Handbook. Fuji Ceramics Co., p.15 (in Japanese).

12. Okayasu M, Yamasaki T. Effects of $90^{\circ}$ domain switching on electric generation properties of PZT ceramic. Ceram Int 2017, 43: 3590-3600. 


\section{Figures}

\section{(a) PZT ceramic}

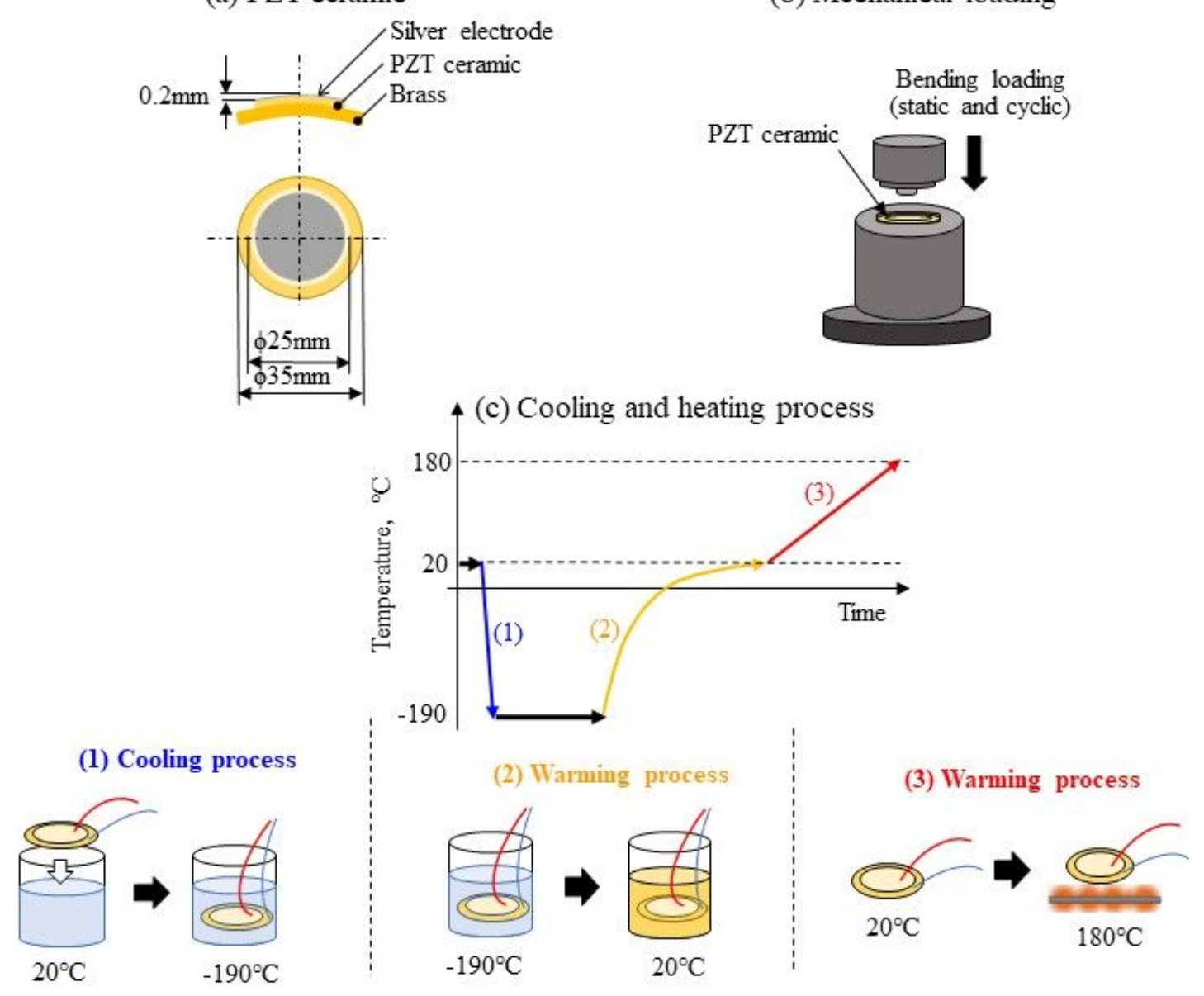

\section{Figure 1}

Schematic diagrams of (a) the PZT ceramic plate, (b) the mechanical loading process, and (c) the cooling and heating processes for investigating the voltage. 


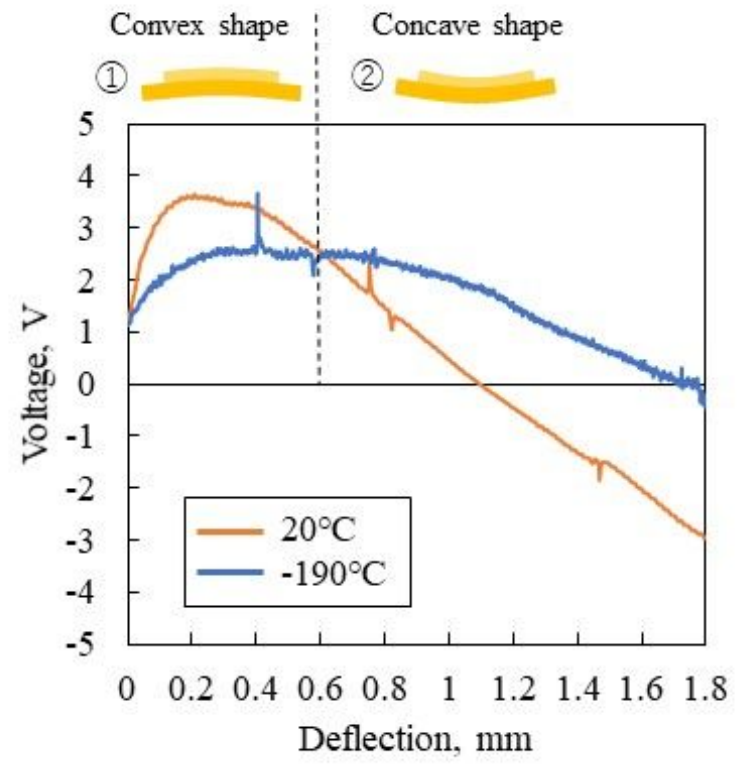

Figure 2

Variation of the voltage during static bending loading at $-190{ }^{\circ} \mathrm{C}$ and $20^{\circ} \mathrm{C}$. 


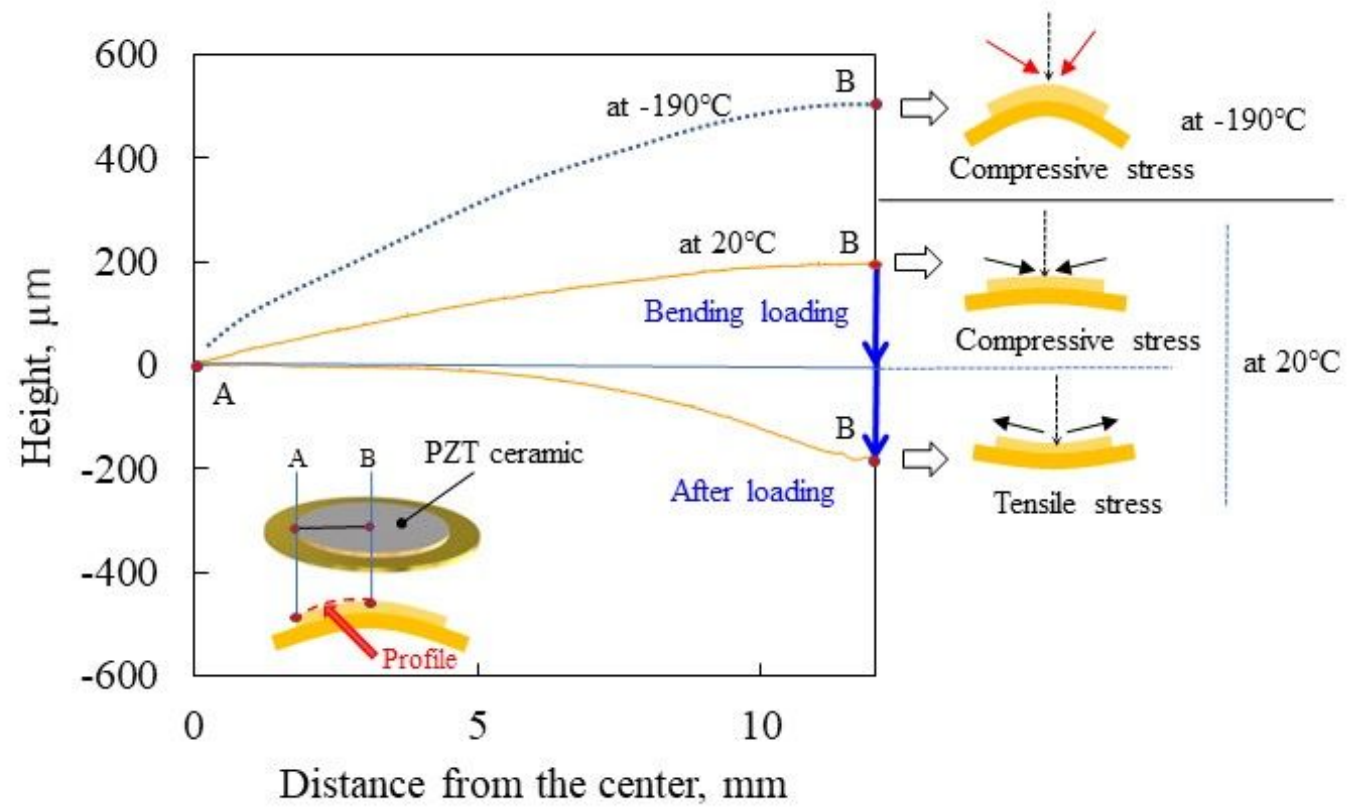

Figure 3

Profile of the PZT ceramic before and after static loading at $-190{ }^{\circ} \mathrm{C}$ and $20^{\circ} \mathrm{C}$. 


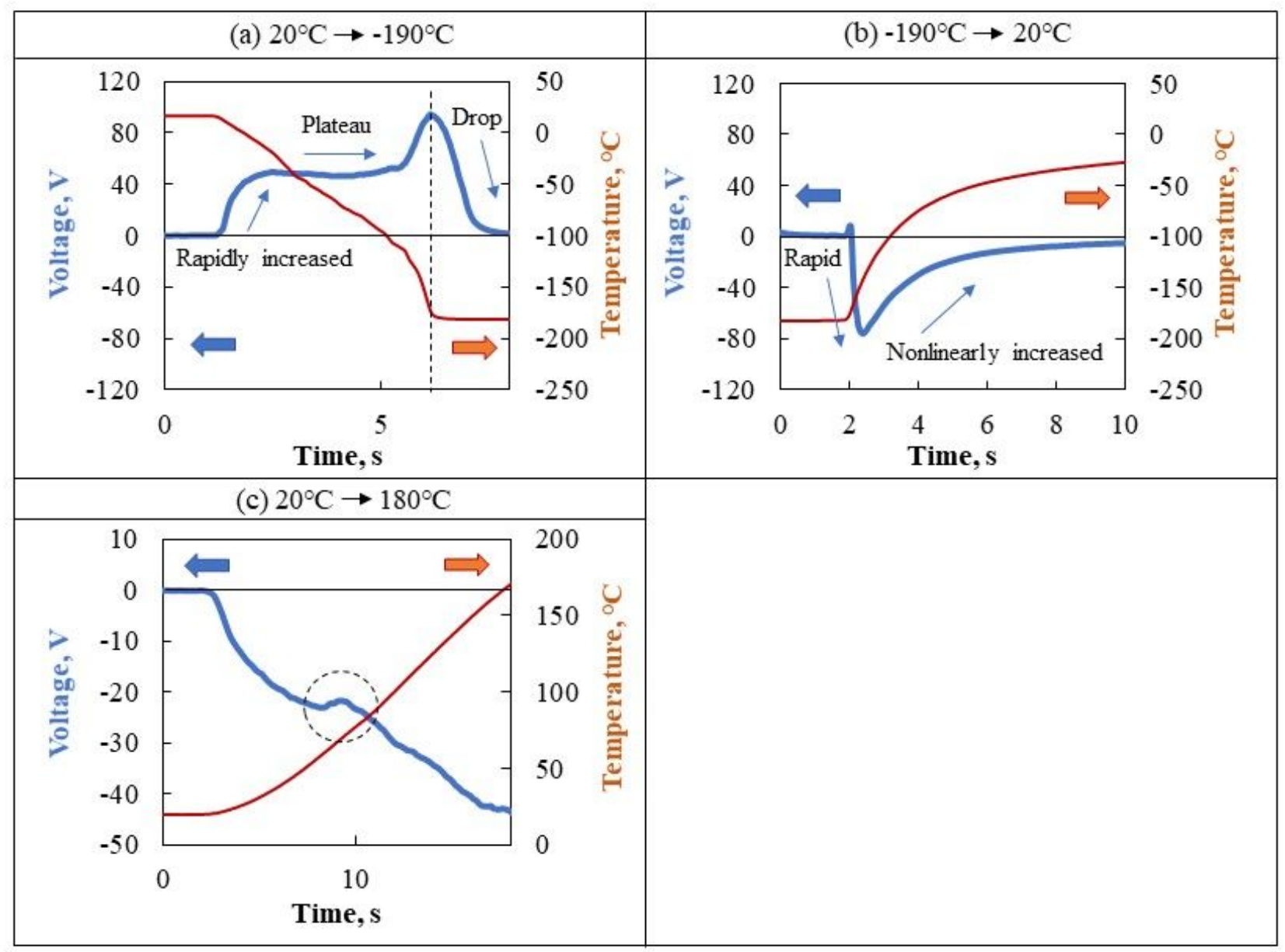

Figure 4

Variation of voltage with sample temperature: (a) cooling from $20^{\circ} \mathrm{C}$ to $-190^{\circ} \mathrm{C}$; (b) heating from -190 ${ }^{\circ} \mathrm{C}$ to $20^{\circ} \mathrm{C}$; and (c) heating from $20^{\circ} \mathrm{C}$ to $180^{\circ} \mathrm{C}$. 


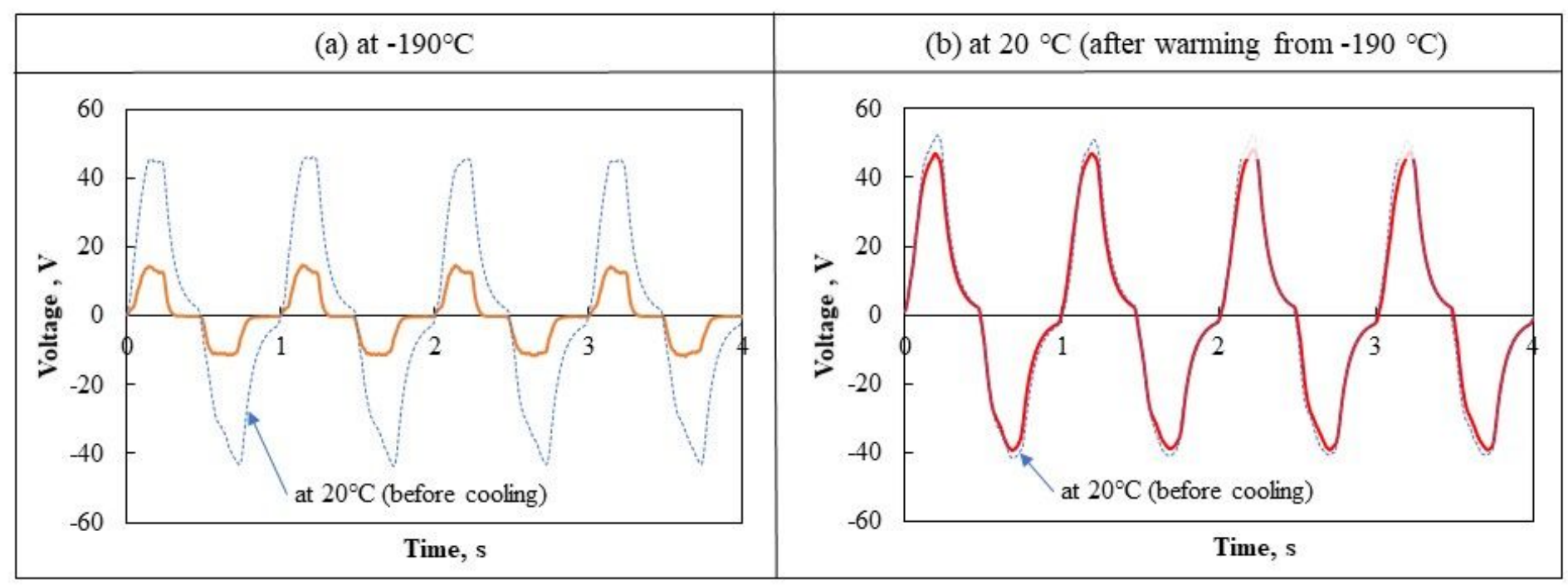

Figure 5

Variation of the electric voltage generated by the PZT ceramic under cyclic loading at $-190^{\circ} \mathrm{C}$ and $20^{\circ} \mathrm{C}$. 


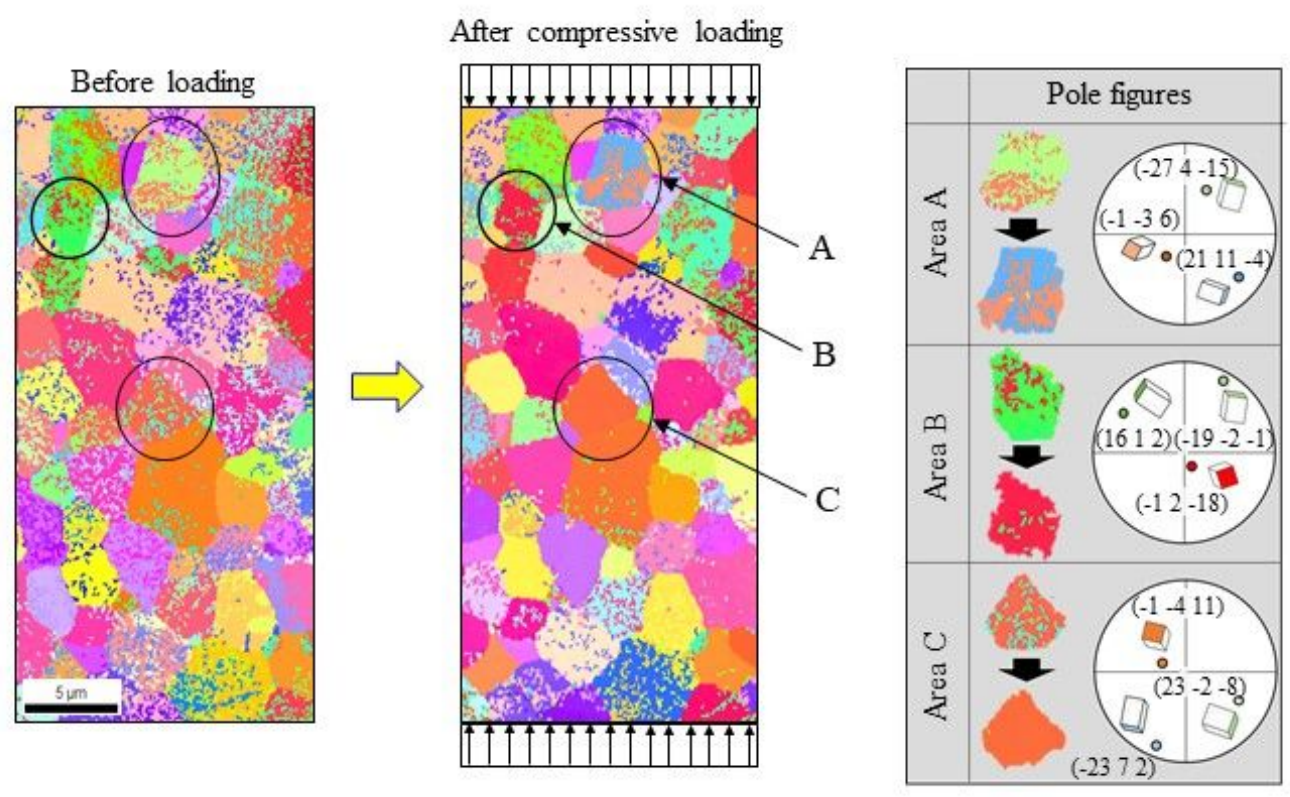

Figure 6

EBSD analysis of the PZT ceramic before and after static loading, showing the $90^{\circ}$ domain switching. 